\title{
Fatty acid content of lipids of milk of ewes of Ukrainian gornokarpatska breed in different conditions of their contents
}

\author{
P. Stapai, doctor of agricultural sciences \\ V. Gavriliak, doctor of biological sciences \\ N. Stahiv, N. Paraniak, A. Skorohid, candidates of agricultural sciences \\ Institute of Animal Biology, National Academy of Sciences of Ukraine
}

The purpose. To study fatty acid content of butter oil of ewes of Ukrainian gornokarpatska breed, growing in different zones of Carpathians, in particular in lowlands and foothill. Methods. Biochemical, statistical. General lipids from milk were extracted using Folch method. For deriving methylated ethers of fatty acids they methylated using method of straight interesterification at availability of accelerant. Results. In butter oil of ewes of Ukrainian gornokarpatska breed they detected 42 fatty acids with chain length beginning from $\mathrm{C} 4$ up to $\mathrm{C} 24$ among which there were acids with twin and unpaired amount of carbon, and also branchy iso- and anteiso-acids and acids with cis-configuration and trans-forms. It was shown that conditions of growing ewes essentially influenced quantitative and quality fatty acid content of butter oil. That was connected with different character of their feeding which in its turn influenced direction of fermentation processes in a rumen of an animal. Conclusions. Fat-acid content of milk of ewes grown in different conditions had essential differences depending on definite factors. Among them the most essential were conditions of growing ewes and character of their feeding which factors influenced direction of fermentation processes in a rumen, level of dairy productivity and biological value of milk.

Key words: ewes, milk, butter oil, fatty acids, biohydrogenation, conditions of growing.

Fatty acid composition of milk lipids in ruminants, unlike monogastric milk, does not fully reflect the fatty acid composition of diet rations. This is due to the fermentation processes in the rumen, the course of which is largely dependent on the amount and ratio in the carbohydrate component of the diet. Ruminants consume feed containing mainly polyunsaturated fatty acids - linoleic and linolenic. However, under the influence of microflora enzymes, these acids are almost completely hydrogenated to steric acid and different amounts of spatial and positional isomers of oleinic and linoleic acids, that is, intermediate metabolites of biohydrogenation. Intermediate metabolites of biohydrogenation of linoleic and linolenic acids - diene conjugates are biologically active compounds that have a positive effect on the metabolism of humans, prevent a number of oncological and cardiovascular diseases [1,2].

Data on the fatty acid composition of sheep's milk obtained under different conditions have theoretical and practical significance, since the quality of the products made from it depends on the quantity and quality of the fatty acids.

Analysis of recent research and publications. In sheep's milk, there are more than 200 nutritious and biologically active substances, the most important of which are protein, fat, milk sugar, vitamins, minerals and others. [3]. Lipids are important components of milk due to their energy value and biological activity, physical and sensory characteristics that are transmitted to dairy products.

The biological value of milk fat depends on the quantitative composition and the ratio of fatty acids in it. The fatty acid content of milk fat is over $85 \%$. The largest group (over $80 \%$ ) consists of triacylglycerols, which contain a large number of esterified fatty acids. Also in milk lipids there are diacylglycerols, monoacylglycerols, unesterified and esterified cholesterol, other sterols, as well as phospholipids. The fraction of the latter is more than $1 \%$ of all lipids [4].

Lipids are in the form of globules of less than 3.5 microns, which is important for digestion and more effective lipid metabolism. About the biological role of certain fatty acids for the human body, in particular, the unique fatty acids, available only in milk of ruminant (butyric acid, branched fatty acids cis-9, trans-11 $(C L A)$ and their precursor vaccine acid, etc.), recently in many interesting letters appeared in the literature $[5,6]$. In particular, it has been shown that some fatty acids (oily, 13-methyltetradecanoic (13-MTDK), trans11 C18: 1, etc.) have anti-carcinogenic properties [7].

True, along with the positive effects of trans-isomers of unsaturated fatty acids, some of them, in particular trans-9 and trans-10 C18: 1, have a negative effect on metabolic processes in the human body. However, it is believed that the most undesirable fatty acids of milk fat are mid-chain fatty acids C12: 0, C14: 0 and C16: 0, because they increase the level of cholesterol and low density lipoprotein in the blood, thus 
revealing atherogenic and thrombogenic properties [8]. In contrast to these acids, monounsaturated, especially polyunsaturated fatty acids $n-3$ and $n-6$, have anti-atherogenic and anti-thrombogenic properties.

Approximately $25 \%$ of all acids falls on cis-forms. It should be noted that cis-forms are less stable than trans forms and therefore, under certain conditions (during heating), they can pass into the trans-form. Thus, oleic acid, during heating, converts to a trans-isomerelidine (trans-9 c18:1) acid, which has a much higher heating temperature. By the way, this acid most often occurs in hydrogenated vegetable fats, in particular in margarine.

Previously, we have shown that thanks to the feeding of sheep breeders to the main diet of sulfur additives (in the composition of sodium sulfate) and iodine not only increases the daily milk hopping, but also the fatty acid composition of milk fat is modified to improve its biological value by increasing the content of mono- and polyunsaturated fatty acids and reducing the content of short- and medium-chain saturated fatty acids [9].

Under the conditions of caprine maintenance of sheep breeders in milk fat, the amount of unsaturated fatty acids increases, mainly due to monounsaturated, in particular oleinic, by $62.3 \%$ compared to sheep's milk, which was kept in lowland pastures [10].

The purpose of the research is to study the composition of fatty acids of milk fat of sheep breeds of the Ukrainian mountain-Carpathian breed, which were kept in different areas of the Carpathians, in particular lowland and foothill.

Materials and methods of research. The experiment was conducted in two groups (6 goals in each) of full-time sheep-bacon analogs (age, live weight) of the Ukrainian mountain-Carpathian breed, which were kept in different zones of the Transcarpathian region, in particular, the lowland (Stebivka village, Khust district) and the foothill with the village of Nizhni Vorota, Volovetsky district). All the animals were in the common flock during pasture retention. Samples of milk for research were taken during early milking according to DSTU-4834: 2007. The milk was filtered through several layers of gauze in sterile bottles, tightly closed with crust and placed in the refrigerator, and for preservation, hydrogen peroxide was used. Total milk lipids were extracted according to the Folche method (1973). To obtain methylated esters of fatty acids, their methylation was carried out using a direct transesterification method in the presence of a catalyst. The fatty acid composition was determined by gas-liquid chromatography on a Hewlett Packard HP-6890 gas chromatograph with a flame-ionization detector [11].

Research results. As a result of researches in milk lipids of sheep breeds of the Ukrainian mountainCarpathian breed, 42 fatty acids with chain length from $\mathrm{C}_{4}$ to $\mathrm{C}_{24}$ have been detected. Among them are acids with a pair and odd amount of carbon, as well as branched iso and anthiosic acids and cisconfiguration acids and trans-forms. With an odd amount of carbon found 8 fatty acids, among which the highest percentage belongs to the family of margarine $\left(\mathrm{C}_{17: 0}\right.$, iso and anteoso- $\left.\mathrm{C}_{17: 0}\right)$ acids. Interestingly, in the milk of cattle, which were kept in the foothills, unsaturated $C_{15: 1}$ and $C_{17: 1}$ were not detected, and the amount of $\mathrm{C}_{17: 0}$ (margarine) acid in it was significantly higher $(\mathrm{P}<0.01)$ in comparison to milk of sheep breeders, which were kept in the lowland zone. Fatty acids of milk lipids can be divided into 3 groups: shortchain $\left(\mathrm{C}_{4}-\mathrm{C}_{10}\right)$ that can be synthesized de novo in the secretory cells of the mammary gland; medium-chain $\left(\mathrm{C}_{12}-\mathrm{C}_{16}\right)$ that can be synthesized de novo (or be of humoral origin), and long-chain, coming from the blood. Fatty acids, which are synthesized by de novo, make up about $45 \%$ of the total, the rest are of fodder origin, and can also come from adipose tissue.

The share of iso- and anethiosic acids accounts for only 2 acids $\left(\mathrm{C}_{14: 0}\right.$ and $\left.\mathrm{C}_{17: 0}\right)$, which amount to 1.80 (low maintenance) and $1.75 \%$ (fore-keeping), the significant differences between the groups studied do not discovered It is known from the literature that isoacids have anti-tumor properties, but it is better in isopalmitinic acid $\left(\mathrm{C}_{16: 0}\right)$ [5]. Among the short-chain fatty acids, the greatest interest is butyric acid $\left(\mathrm{C}_{4: 0}\right)$. This unique milk fat acid is synthesized by de novo in the secretory cells of the mammary gland. It has anticarcinogenic properties by inducing differentiation, apoptosis, and inhibiting proliferation and angiogenesis [5]. The energy value of this acid is the smallest among all fatty acids $-5.92 \mathrm{kcal} / \mathrm{g}$, while stearic $\left(\mathrm{C}_{18: 0}\right)$ $9.48 \mathrm{kcal} / \mathrm{g}$. Under different conditions, the maintenance of sheep breeds in their milk did not reveal any significant differences in the content of this acid. The number of all short-chain fatty acids $\left(C_{4: 0}-C_{10: 0}\right)$ is higher in lipid milk of sheep under conditions of their low maintenance (Table 1). Moreover, for acids $\mathrm{C}_{6: 0}$ and $\mathrm{C}_{8: 0}$ these differences are probable $(\mathrm{P}<0.01$ and $\mathrm{P}<0.001)$. It is possible that precisely thanks to the shortchain saturated fatty acids and increased the saturation of milk fat for sheep breeds of this group. The highest percentage among saturated fatty acids is palmitic acid $\left(\mathrm{C}_{16: 0}\right)$. The content of the latter is almost the same in the milk fat of both groups (22.77 and $23.01 \%)$, while the stearic acid content $\left(\mathrm{C}_{18: 0}\right)$ is almost three times less. The amount of this saturated fatty acid is higher in lactating dairy fat, which was kept in the foothills zone ( 14.16 vs. $8.84 \%, \mathrm{P}<0.01)$. 
Different conditions for the maintenance of sheep breeds, and, consequently, their different nature, their nutrition, significantly affect the qualitative composition of fatty acids of milk fat. In particular, more unsaturated fatty acids appeared in milk of sheep breeders, which were kept in the foothill zone (34.18 vs. $31.69 \%$ ). It was found that an increase in the unsaturation of milk fat occurred only due to monounsaturated fatty acids (29.63 vs. $26.43 \%)$ due to oleic acid $\left(\mathrm{C}_{18: 1}\right)$.

Thus, in milk fat of this group of sheep breeds it is $25,17 \%$ of this acid, which is by $37,5 \%$ more compared with the milk fat of sheep breeders, which was kept in the low zone $(P<0,001)$. Among the seven oleic acid isomers, 6 of them are in smaller quantities (Table 2). Particularly low percentages (1.02 vs. 5.83\%) belong to the biologically active acid - vaccine (trans-11 $\mathrm{C}_{18: 1}$ ), resulting in an amount of acids of the family $\mathrm{C}_{18: 1}$ dominated by only $12.3 \%$.

At the same time, in lactating dairy fats, which were kept in the lowland zone, there is a somewhat higher content of polyunsaturated fatty acids (5.26 vs. $4.55 \%)$, in particular, linoleic $\left(\mathrm{C}_{18: 2}, 3.46\right.$ against $\left.2.89 \%\right)$, linolenic $\left(C_{18: 3}, 1.34\right.$ vs. $\left.0.95 \%\right)$. Among the two isomers of linoleic acid, cis-9, cis-12 $C_{18: 2}(2-2.3 \%)$ is dominant, but no significant intergroup differences were found, as, incidentally, with scar tissue conjugate acid (cis- 9, trans-11 $\mathrm{C}_{18: 2,}, 0.56-0.49 \%$ ) (see Table 2).

It is believed that the modification of the fatty acid composition of milk fat should be carried out in the direction of reducing saturated fatty acids, especially mid-chain, and increasing the unsaturated fatty acids, especially vaccine (trans-11 $\mathrm{C}_{18: 1}$ ) and scarring conjugated (cis-9, trans- $11 \mathrm{C}_{18: 2)}$ ). It should be noted that the major precursor of trans-isomers in milk fat is trans- $11 \mathrm{C}_{18: 2}$ vaccine and its derivative cis-9, trans-11 $\mathrm{C}_{18: 2}$ - conjugated linoleic acid [12].

The multidimensional biological effects of isomeric forms of fatty acids of milk fat, in particular trans-11 isomers, which are formed only in the process of scar fermentation, are now experimentally proved, and therefore are specific for milk fat in ruminants.

The main products of biohydrogenation are sclerosing isomers (cis-9, trans-11 $C_{18: 2}$ ) and vaccine (trans$\left.11 \mathrm{C}_{18: 1}\right)$ acids. Rubic acid is formed in the body of animals and human from vaccine acid as a result of the action of 9-stearoyldestaurazy [5], and has anti-carcinogenic, anti-sclerotic and immunostimulant properties [9]. Unlike these isomers of biologically active diene conjugates, other trans isomers, in particular trans-10 $\mathrm{C}_{18: 1}$ and trans-10, cis-12 C18: 2, can negatively affect the body $[2,10]$.

Consequently, the fatty acid composition of milk obtained in different conditions is quite different, and therefore, in each particular case, it is necessary to take into account those factors that most influence the formation of quantitative and qualitative parameters of fatty acids. Among all these factors, the most significant, we consider, are the conditions for the maintenance of sheep breeds and the nature of their nutrition (composition and nutrition of rations), on which the direction of fermentation processes in the rumen, the level of milk productivity and the biological value of milk depend to a large extent.

\section{Conclusions}

There were no unsaturated $\mathrm{C}_{15: 1}$ and $\mathrm{C}_{17: 0}$ fatty acids in the milk of cattle that were kept in the foothills zone, and the amount of margaric acid $\left(\mathrm{C}_{17: 0}\right)$ in it was significantly higher in comparison with the milk of sheep breeders, which were kept in the lowland zone. More unsaturated fatty acids were found in milk fat from sheep breeders from the foothills zone, and this increase was due to monounsaturated, in particular, oleic acid. In milk, bovine animals from the lowland zone have a higher percentage of polyunsaturated fatty acids of linoleic and linolenic, and the dominant isomer is cis-9, cis-12 $\mathrm{C}_{18: 2 .}$.

\section{Bibliography}

1. Vudmaska I.V. Izomernyy sklad zhyrnykh kyslot moloka koriv pry zamini chastyny klitkovyny ratsionu tsukrom/I.V. Vudmaska, O.V. Holubets'//Nauk.-tekhn. byul. — 2008. — Vyp. 9, № 1, 2. - S. 89 - 93.

2. Holubets' O.V. Vplyv bufernoyi dobavky na zhyrnokyslotnyy sklad lipidiv vmistu rubtsya koriv za riznoho rivnya vuhlevodiv u ratsioni/O.V. Holubets'//Tam samo. - 2009. - Vyp. 10, № 1 - 2. - S. $144-$ 149.

3. Myllz O. Molochnoe ovtsevodstvo/O. Myllz. - M.: Ahropromyzdat, 1985. - $244 \mathrm{~s}$.

4. Sydir N.P. Vmist i sklad lipidiv moloka vivtsematok ukrayins'koyi hirs'kokarpat-s'koyi porody i porody prekos za umov z-hodovuvannya yim pidvyshchenykh rivniv makro- i mikroelementiv ta fil'troperlitu/N.P. Sydir, P.V. Stapay//Nauk.-tekh. byul. IBT NAAN i DNDKI vetpreparativ ta kormovykh dobavok. - 2012. Vyp. 13, № $3-4$. - S. $82-86$.

5. Tsisaryk O.Y. Zhyrnokyslotnyy sklad molochnoho zhyru koriv/O.Y. Ts isaryk, H.V. Dronyk//Biolohiya tvaryn. - 2008. - T. 10, № $1-2$. - S. $84-102$.

6. Parodi P.W. Nutritional significance of milk lipids/P.W. Parodi//J. Am. Col. Nutr. $-2005 .-25 .-$ P. $556 S-568 S$. 
7. Park Y.W. Goat milk - chemistry and nutrition/Y.W. Park, G.F.W. Haenlein//(Eds.), Handbook of Milk of Non-bovine Mammals. Blackwell Publishing Professional, Oxford, UK/Ames, lowa. - 2006. - P. $34-58$.

8. Revilla I. Changes in ewe's milk composition in organic versus conventional dairy farms/l. Revilla, M.A. LuruenaMartinez//Czech. J. Food Sci. - 2009. - 27. - P. $263-266$.

9. Sydir N.P. Zhyrnokyslotnyy sklad lipidiv moloka ovets' ukrayins'koyi hirs'kokarpat-s'koyi porody za umov pidvyshchenoho rivnya sirky i yodu $v$ yikh ratsionakh/N.P. Sydir, P.V. Stapay//Biolohiya tvaryn. 2011. - T. 13, № 1 - 2. - S. 231 - 239.

10. Burda L.R. Zhyrnokyslotnyy sklad moloka ovets' ukrayins'koyi hirs'kokarpat-s'koyi porody pry vypasanni na polonynnykh ta nyzynnykh pasovyshchakh/L.R. Burda//Tam samo. - 2009. - T. 11, № $1-2$. - S. $155-160$.

11. Holubets' O.V. Vyznachennya zhyrnokyslotnoho skladu lipidiv metodom kapilyarnoyi hazoridynnoyi khromatohrafiyi: metod. rekom./O.V. Holubets', I.V. Vudmaska. — L'viv, 2010. — 37 s.

12. Sydir N.P. Mineral'nyy sklad moloka vivtsematok za z-hodovuvannya yim makro- i mikroelementiv ta fil'troperlitu/N.P. Sydir, P.V. Stapay, H.M. Sedilo//Sil's'kyy hospodar. — 2012. — № 9-10. — S. 8 - 11 . 